\title{
Strategi Pengemasan dan Pelabelan Produk Jajanan Jadul di Kelurahan Siwalan Kecamatan Gayamsari Semarang
}

\author{
Rita Meiriyanti, C Tri Widiastuti, Rahmatya Widyaswati \\ Fakultas Ekonomi, Universitas Semarang, Indonesia \\ rita.mey15@gmail.com
}

Received: $24^{\text {th }}$ February 2020 | Accepted: $29^{\text {th }}$ July 2020 | Publihsed: $20^{\text {th }}$ August 2020

Key word:

Packaging;

Labeling;

Businessman of

old snack

Kata Kunci

Pengemasan;

Pelabelan;

Pelaku Usaha

Jajanan Jadul

\section{Abstract}

Businessman of old snack in Thematic Village, Siwalan Village, their marketing is still very limited and traditionally managed. Business actors also didn't have proper product packaging and labeling. The aim of the Community Service Program is businessman of old snack able to implement packaging and labeling strategies in developing their products and spreading their market. This dedication activity is carried out with marketing management counseling methods, assistance in making packaging and labeling. The results of this activity are the businessman mastery of the packaging and labeling strategy and can apply simply online based marketing. Businessman of old snack are very enthusiastic to participate in this community service.

\section{Abstrak}

Pengusaha jajan jaman dulu (jadul) di Kampung Tematik, Desa Siwalan, pemasarannya masih sangat terbatas dan dikelola secara tradisional. Pelaku usaha juga belum melakukan pengemasan dan label produk yang baik dan memadai. Tujuan dari Program Pengabdian kepada Masyarakat adalah pengusaha jajanan jadul mampu menerapkan strategi pengemasan dan pelabelan dalam mengembangkan dan memasarkan produknya. Kegiatan pengabdian ini dilakukan dengan metode penyuluhan manajemen pemasaran, pendampingan pembuatan packaging dan labeling. Hasil dari kegiatan ini adalah pelaku bisnis menguasai strategi pengemasan dan pelabelan serta dapat menerapkan pemasaran berbasis online secara sederhana. Pengusaha jajan jadul yang menjadi mitra sangat antusias mengikuti pengabdian masyarakat ini. 


\section{PENDAHULUAN}

Kampung Tematik merupakan satu di antara inovasi Pemerintah Kota Semarang untuk mengatasi permasalahan pemenuhan kebutuhan dasar, utamanya pada peningkatan kualitas lingkungan rumah tinggal warga miskin dan prasarana dasar permukiman. Kampung tematik di Kota Semarang ini merupakan titik sasaran dari sebagian wilayah yang melakukan perbaikan dengan memperhatikan beberapa hal, diantaranya yaitu mengubah lokasi kumuh menjadi tidak kumuh, peningkatan penghijauan wilayah, pelibatan masyarakat secara aktif, perbaikan kondisi lingkungan menjadi lebih baik dan mengangkat potensi sosial serta ekonomi masyarakat pada wilayah tersebut (Martuti, 2019).

Keikutsertaan masyarakat setempat beserta lembaga-lembaga yang ada bertujuan untuk membangun trademark, pengembangan potensi lokal yang dimiliki wilayah tersebut serta membangun karakteristik lingkungan. Potensi-potensi yang dapat diangkat dengan keikutsertaan masyarakat tersebut dapat berupa usaha masyarakat yang dominan, membangun karakter masyarakat yang mendidik (budaya, tradisi, kearifan lokal), home industri yang ramah lingkungan, serta ciri khas dari masyarakat setempat yang tidak dimiliki di kampung lain dan tentunya dapat menjadi ikon wilayah (Akbar, 2018). Berdasarkan informasi di kecamatan Gayamsari, kelurahan Siwalan terdapat kampung tematik yang membuat aneka jajanan jaman dulu (jadul). Terdapat lebih dari 100 pelaku usaha jajanan jadul di Kecamatan Gayamsari yang berprofesi sebagai pembuat jajanan jadul dari generasi ke generasi. Konsumen dapat melihat industri rumahan jajanan jadul di kampung ini. Kampung ini mengolah berbagai macam makanan jadul seperti bakpao, bolu kukus, bolang baling, molen, kue putu, sentiling singkong, dan sebagainya.

Pemasaran yang dilakukan oleh pelaku usaha tersebut sebagian besar masih menggunakan sistem penjualan dari mulut ke mulut (word of mouth), hingga lamakelamaan beberapa konsumen datang sendiri ke kampung tersebut untuk membeli langsung produk jajanan jadul. Jajanan jadul yang dihasilkan, selama ini hanya dijual ke pedagang di pasar atau diambil oleh pedagang di tempat produksi (Wijayanti \& Suratman, 2019). Contoh jajanan jadul yang diproduksi di kampung tematik jajanan jadul adalah sebagai berikut: 


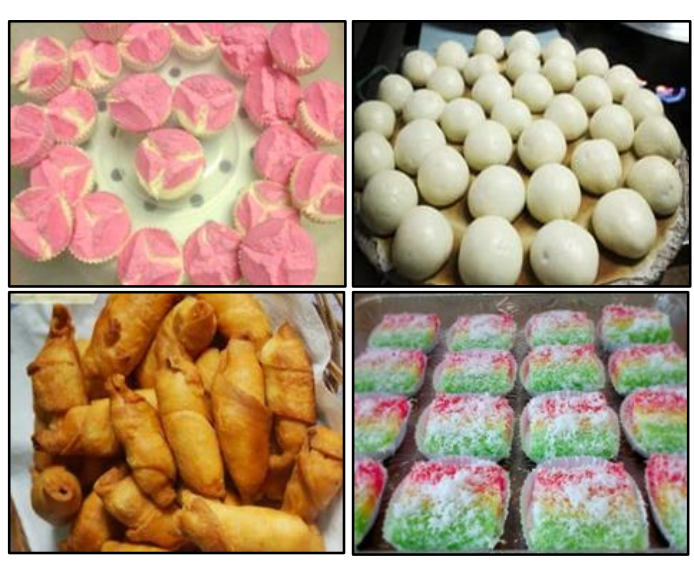

Gambar 1. Contoh Jajanan Jadul yang diproduksi di Kampung Tematik Siwalan

Jajanan jadul yang diproduksi di kampung ini belum dikemas dengan menarik. Umumnya mereka hanya mengemas dengan plastik dan ada juga yang disajikan tanpa kemasan. Selain itu juga belum ada pemberian label yang terdapat dalam kemasan sebagai sarana penyampaian informasi produk kepada konsumen.

Penampilan produk yang dapat memikat pelanggan sangat ditentukan oleh Labeling dan Packaging. Pandangan pertama konsumen sangat menentukan pilihan para konsumen sehingga penampilan produk sangat penting untuk menarik minat konsumen di pasaran (Irrubai, 2015).

Berdasarkan uraian diatas Tim Pengabdian merasa perlu memberikan penyuluhan dan pendampingan kepada pelaku usaha jajanan jadul di Kelurahan Siwalan, Kecamatan Gayamsari. Karena kelurahan Siwalan sudah dijadikan sebagai kampung tematik jajanan jadul, maka untuk mampu mempertahankan eksistensi jajanan jadul para pelaku usaha perlu mengetahui pentingnya labelling dan packaging untuk produknya.

Berdasarkan hasil interview prasurvey dengan pelaku usaha jajanan jadul di kampung tematik jajanan jadul kelurahan Siwalan kecamatan Gayamsari, permasalahan mitra antara lain :

1. Para pelaku usaha jajanan jadul di Kampung Tematik Jajanan Jadul Kelurahan Siwalan, pemasarannya masih sangat terbatas dan dikelola secara tradisional.

2. Para pelaku usaha jajanan jadul di Kampung Tematik Jajanan Jadul Kelurahan Siwalan, belum memahami pentingnya pengemasan dan pelabelan produk. Produk jajanan jadul mereka belum mempunyai label sehingga masyarakat kesulitan mengenali produk apabila ingin memesan kembali. Pengemasan juga masih sangat tradisional sehingga membuat produk kurang menarik.

Kondisi tampilan jajanan jadul saat ini dan pentingnya pengemasan serta pemberian label pada makanan untuk mendongkrak sales atau penjualan dan meningkatkan pengetahuan orang di luar Kecamatan Gayamsari tentang produk jajanan jadul 
kemudian menjadikan tim pengabdi memilih untuk melakukan penyuluhan dan pendampingan strategi pengemasan dan pelabelan produk. Pendampingan pada pelaku usaha jajanan jadul yakni pengemasan yang baik dan pentingnya label pada sebuah produk diharapkan mampu meningkatkan kualitas dari jajanan jadul.

\section{METODE}

Salah satu metode yang dapat diterapkan untuk pemberdayaan masyarakat khususnya memberikan pemahaman baru yaitu pendampingan partisipatif (Mustanir dkk., 2019). Metode ini dapat dikembangkan dengan Anjangsana dan Anjangkarya. Penyuluhan yang dilakukan oleh seorang penyuluh dapat bersifat anjangsana dengan melakukan kunjungan kepada sasarannya secara perorangan maupun kelompok baik di rumah/tempat tinggal atau anjangkarya di tempat mereka biasa melakukan kegiatan sehari-hari (Supriyono \& Sumardiyono, 2018).

Berdasarkan analisis kebutuhan dan permasalahan yang dihadapi oleh pelaku usaha jajanan jadul, metode yang digunakan oleh Tim Pengabdian kepada Masyarakat adalah:

1. Penyuluhan manajemen pemasaran kepada pelaku usaha jajanan jadul. Pendampingan pembuatan pengemasan dan pelabelan.

\section{HASIL}

Pelaksanaan kegiatan pengabdian oleh Tim Pengabdian Masyarakat Fakultas Ekonomi diawali dengan pemberian materi mengenai dasar manejemen pemasaran, strategi promosi melalui pengemasan dan pelabelan, contoh kemasan dan label produk jajanan jadul. Dilaksanakan di Balai Kelurahan Siwalan Kecamatan Gayamsari yang dihadiri 10 peserta. Adapun hasil pelaksanaan kegiatan Pengabdian kepada Masayarakat dapat di uraikan sebagai berikut:

1. Penyuluhan Manajemen Pemasaran.

Penyuluhan manajemen pemasaran sangat penting dilakukan mengingat promosi jajanan jadul di kampung tematik jajanan jadul masih terbatas. Pelaku usaha dituntut untuk lebih jeli dalam hal pemasaran untuk mempertahankan eksistensinya.

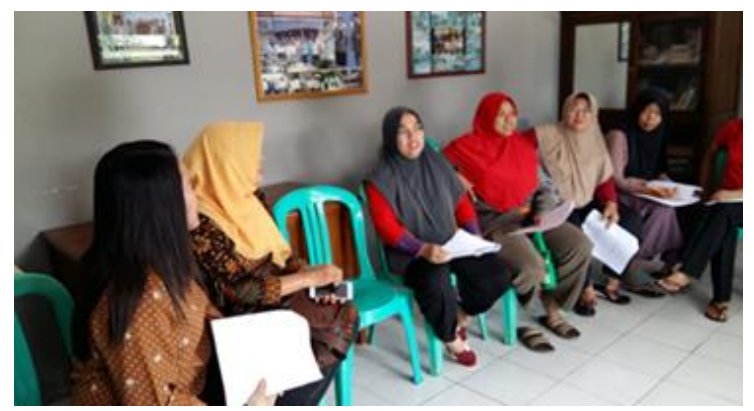

Gambar 2. Tim PKM sedang menjelaskan tentang dasar manajemen pemasaran

Penguasaan media promosi untuk pelaku usaha di kampung tematik jajanan 
jadul kelurahan Siwalan yang bergerak di bidang pembuatan jajanan jadul ini hanya memasarkan produknya dari mulut ke mulut, dijual secara keliling dan dititipkan di toko-toko/pasar. Adapun beberapa kosumen yang datang sendiri ke tempat produksi. Dari segi kemasan, jajanan jadul tersebut juga belum dikemas secara higienis dan menarik untuk menambah minat pembeli, hanya dikemas dalam plastik bahkan seringkali disajikan tanpa kemasan dan label.

Minimnya pengetahuan tentang pemasaran juga menjadi salah satu faktor yang memungkinkan pelaku usaha jajanan jadul berjalan di tempat. Diperlukan informasi yang lebih luas lagi agar masyarakat dapat mengetahui adanya produk jajanan jadul yang merupakan ikon kampung tematik jajanan jadul di kelurahan Siwalan Kecamatan Gayamsari.

Kegiatan pengabdian kali ini membuka pemahaman pelaku usaha bahwa pemasaran yang tepat dapat meningkatkan penghasilan. Mitra pengabdian juga diberikan pemahaman mengenai bagaimana menggunakan alat komunikasi dalam hal ini ponsel pintar (smartphone) sebagai alat untuk pemasaran produk.

Media sederhana yang digunakan adalah Whatsapp dan Facebook dan peserta diberikan pengetahuan praktis dalam memilih foto serta narasi menarik dalam memasarkan produk jajanan jadul.

2. Pendampingan pembuatan pengemasan dan pelabelan.

Pendampingan pembuatan pengemasan dan pelabelan sangat penting dilakukan mengingat kurangnya pengetahuan tentang pengemasan dan pelabelan. Pada dasarnya pengemasan merupakan kunci utama dari sebuah produk. Apabila suatu produk yang sudah memiliki rasa yang enak namun pengemasannya kurang menarik akan mengakibatkan konsumen tidak tertarik untuk membeli produk tersebut. Sebaliknya apabila sebuah produk telah dikemas dengan menarik, maka konsumen akan datang sendiri untuk membeli produk tersebut. Berikut ini gambar kegiatan tim PKM pada saat pendampingan pengemasan dan pelabelan :

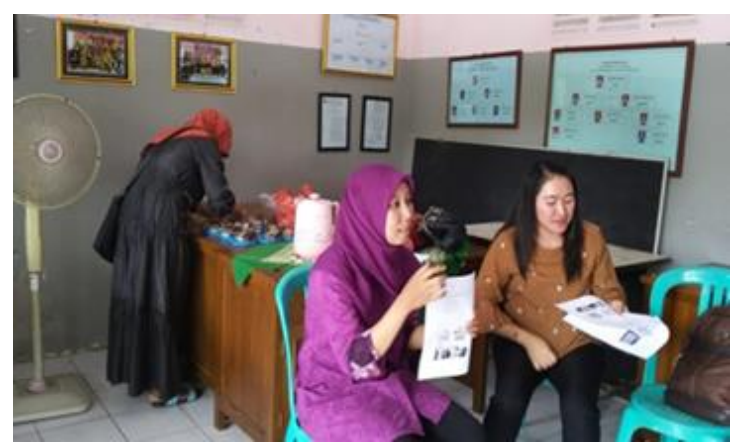

Gambar 3. Tim PKM sedang menjelaskan strategi promosi melalui pengemasan dan pelabelan

Kemasan memiliki peran yang sangat penting untuk produk yang dikemas sebagai penampilan pertama dari citra pemasaran suatu produk. Kemasan bisa memberikan 
perlindungan produk dengan baik dari cuaca, cahaya/sinar, perubahan suhu, jatuh, tumpukan, kotoran, serangga, bakteri dan lain-lain. Bentuk dan ukuran menarik sesuai dengan kebutuhan menciptakan daya tarik visual bagi konsumen.

Kegiatan pengabdian kepada masyarakat ini mampu meningkatkan pemahaman kepada pelaku usaha jajanan jadul di kampung tematik jajanan jadul kelurahan Siwalan tentang pembuatan label sederhana yang memuat informasi nama jajanan dan nomor telepon produsen jajanan. Lebih lanjut tim pengabdi menyampaikan sarana atau aplikasi yang dapat digunakan untuk mendesain label sederhana. Tim pengabdi juga memberikan saran agar pelaku usaha bekerjasama dengan percetakan atau pelaku usaha desain setempat agar label dan kemasan yang dimiliki lebih menarik.

Setelah mendapatkan materi mengenai kemasan, higienitas, dan labeling, para pelaku usaha yang menjadi mitra dapat memahami tingkat kepentingan memiliki label sendiri serta membuat kemasan yang menarik minat konsumen agar membeli jajanan jadulnya.

Berikut ini gambar perbandingan produk jajanan jadul sebelum dan sesudah menggunakan kemasan

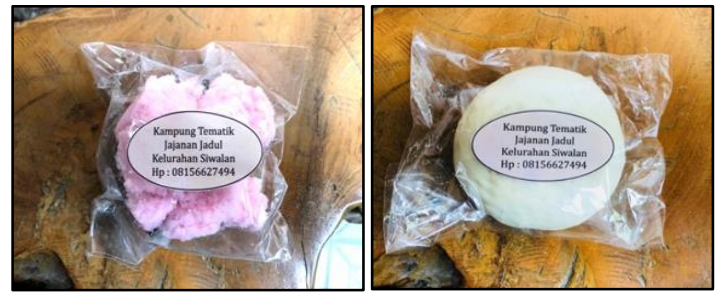

Gambar 4. Produk Jajanan Jadul Setelah Menggunakan Kemasan dan Label

\section{PEMBAHASAN}

Kehadiran aplikasi sosial media, seperti Whatsapp dan Facebook di smartphone memudahkan pelaku usaha dalam berkomunikasi terhadap pelanggan ataupun berkomunikasi dengan sesama pelaku usaha (Juwariyah \& Krisnawati, 2019)

Kemasan yang baik harus mempunyai fungsi efisien dan ekonomis. Efisien maksudnya penggunaan kemasan pada produk memberikan kemudahan kepada konsumen. Toko-toko besar umunya mengutamakan kemasan dalam menerima produk untuk dijual di tokonya (Hidayat \& Triharyanto, 2016).

Pemberian label yang terdapat dalam kemasan merupakan sarana penyampaian informasi produk kepada konsumen. Mulamula produk jajanan jadul belum dikemas secara higienis dan menarik untuk menambah minat pembeli, hanya dikemas dalam plastik bahkan seringkali disajikan tanpa kemasan dan label. Kemudian dikembangkan dengan kemasan mika/plastik yang disertai label merek dan 
informasi lain yang terkait produk. Selain tampilannya menjadi lebih menarik juga memudahkan konsumen dalam mengidentifikasi produk dengan informasi yang terdapat di dalam label. Pemberian kemasan dan label pada produk jajanan jadul dapat menciptakan nilai tambah produk sebagai pembeda dengan produk sejenis, serta guna menjamin produk yang mereka miliki memiliki reputasi baik (Ash Shadiq Egim, 2019).

Evaluasi juga dilakukan pada kegiatan ini agar secara teknis diketahui bahwa beberapa pelaku usaha jajanan jadul sangat antusias untuk menerapkan penggunaan kemasan ke dalam produk mereka, dan memberikan label produk. Diharapkan kedepannya pelaku usaha jajanan jadul dapat menyeragamkan dalam penggunaan kemasan. Tujuan dari evaluasi ini untuk melihat perkembangan program pendampingan yang dilaksanakan di Kelurahan Siwalan, Kecamatan Gayamsari Semarang untuk mengetahui kendala yang dialami pelaku usaha sehingga program pendampingan yang didapatkan benarbenar efektif serta dampak dari program ini dapat berkelanjutan setelah pendampingan selesai dilaksanakan .

Kegiatan sharing serta diskusi dengan pelaku usaha jajanan jadul didapat hasil yang memuaskan. Peserta sangat antusias mengikuti kegiatan dari awal sampai akhir acara. Mengingat kontribusi UKM yang besar bagi perekonomian terutama pendapatan produk domestik bruto, maka peran akademisi dalam membantu pengembangan UKM sangat diperlukan dalam pemberdayaan UKM

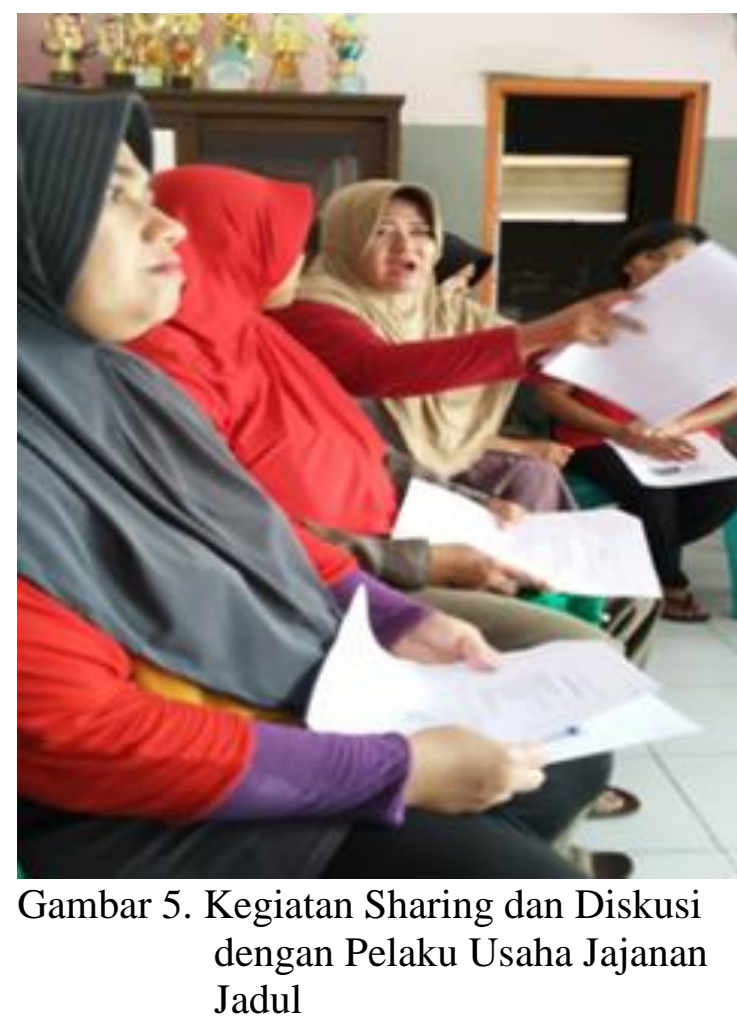

\section{SIMPULAN}

Kesimpulan yang didapat berdasarkan pelaksanaan kegiatan pengabdian kepada masyarakat pelaku usaha jajanan jadul di kelurahan Siwalan kecamatan Gayamsari yang dihadiri oleh 10 peserta telah berjalan lancar. Berdasarkan hasil evaluasi, para peserta mampu menerapkan strategi pemasaran melalui pengemasan dan pelabelan. 


\section{SARAN}

Saran yang dapat disampaikan yaitu pelaku usaha jajanan jadul di kampung tematik jajanan jadul kelurahan Siwalan sebaiknya bisa menyeragamkan dalam hal kemasan. Dengan menggunakan kemasan, jajanan jadul dapat dikembangkan menjadi produk yang memiliki nilai tambah, lebih higienis, dan mampu berdaya saing. Hal ini penting diterapkan pada pelaku usaha jajanan jadul karena selama ini belum terpikirkan oleh pelaku usaha jajanan jadul untuk menciptakan pengemasan dan pelabelan. Kelompok usaha ini termasuk usaha mikro sehingga masih memerlukan penyuluhan dan pendampingan lainnya guna pengembangan usaha terutama dalam hal promosi/pemasaran produk.

\section{UCAPAN TERIMA KASIH}

Tim pengabdi mengucapkan terima kasih kepada LPPM Universitas Semarang atas dukungan dan fasilitas yang diberikan. Ucapan terima kasih juga disampaikan kepada Camat Gayamsari dan Lurah Siwalan serta Mitra Pengabdian para pelaku usaha jajanan jadul di Kelurahan Siwalan yang dengan antusias mendukung kegiatan pengabdian ini berjalan lancar hingga akhir.

\section{DAFTAR PUSTAKA}

Akbar, T. (2018). Kampung Tematik Sebagai Bentuk Partisipasi
Masyarakat Dalam Permasalahan

Permukiman Kumuh Di Kota

Malang. WAHANA, 70(2), 37-48.

Ash Shadiq Egim, N. (2019). Strategi

Pengembangan Industri Makanan

Khas Daerah di Kota Padang

Dengan Pengemasan dan

Pemasaran Berbasis Teknologi.

Jurnal Menara Ekonomi: Penelitian dan Kajian Ilmiah Bidang Ekonomi, $5(3)$.

Hidayat, Y., \& Triharyanto, E. (2016).

Peningkatan Daya Jual Aneka

Produk Olahan Makanan Melalui

Teknik Pengemasan Produk. Jurnal

Kewirausahaan dan Bisnis, 19(10).

Irrubai, M. L. (2015). Strategi Labeling,

Packaging dan Marketing Produk

Hasil Industri Rumah Tangga di

Kelurahan Monjok Kecamatan

Selaparang Kota Mataram Nusa

Tenggara Barat. SOCIETY, 6(1), 15-30.

Juwariyah, T., \& Krisnawati, L. (2019).

Pemanfaatan E-Commerce Bagi

Ibu-Ibu Pengusaha Mikro RT 02

RW 014 Desa Simpangan,

Kecamatan Cikarang Utara.

SABDAMAS, 1(1), 355-361.

Martuti, N. K. T. (2019). Preferensi

Masyarakat Terhadap Program

Kampung Tematik Di Kota 
Semarang. Jurnal Riptek, 11(2), 11-22.

Mustanir, A., Hamid, H., \& Syarifuddin, R.

N. (2019). Pemberdayaan

Kelompok Masyarakat Desa Dalam

Perencanaan Metode Partisipatif.

Moderat: Jurnal Ilmiah Ilmu

Pemerintahan, 5(3), 227-239.

https://doi.org/10.25147/moderat.v5

i3.2677

Supriyono, S., \& Sumardiyono, S. (2018).

IbM Tungku Pembakaran Performa

Tinggi Dengan Bahan Bakar

Limbah Kacang Dieng. ABDIMAS

UNWAHAS, 3(1).

Wijayanti, R., \& Suratman. (2019).

Pembinaan Kewirausahaan

Masyarakat Kelurahan Siwalan

Kecamatan Gayamsari Sebagai

Upaya Pengembangan Kampung

Tematik Jajanan Jadul di Kota

Semarang.

https://repository.usm.ac.id/detail-

pengabdian-128.html 